\title{
Penerapan Layanan Bimbingan Kelompok Dengan Media Audio- Visual Dalam Meningkatkan Minat Belajar Siswa Kelas X Mipa V Pada Masa Pandemi Di Man Kota Palangka Raya
}

\author{
Nurhasanah \\ Universitas Palangka Raya, Palangka Raya, Indonesia \\ nurhasanah310599@gmail.com \\ Romiaty \\ Universitas Palangka Raya, Palangka Raya, Indonesia \\ romiaty@fkip.upr.ac.id
}

\begin{abstract}
Abstrak
Penelitian ini bertujuan untuk melihat hasil peningkatan minat belajar dengan penerapan layanan bimbingan kelompok menggunakan media audio visual. Penelitian ini menggunakan pendekatan kuantitatif deskriptif dan mengunakan metode ekperimen dengan desain one group samples pretest dan posttest. Penelitian ini melibatkan seluruh siswa kelas X MIPA V MAN Kota Palangka Raya sebagai populasi dan pemilihan sampel dengan teknik purposive sampling, terpilih 8 siswa yang dijadikan sebagai sampel. Data dalam penelitian ini diambil menggunakan 30 item angket minat belajar. Berdasarkan hasil analisis data yang diperoleh setelah mendapatkan perlakuan berupa layanan bimbingan kelompok dengan media audio visual sebanyak tiga kali pertemuan, yang menunjukkan adanya peningkatan terhadap minat belajar siswa kelas X MIPA V MAN Kota Palangka Raya. Hasil penelitian ini diperoleh nilai $t_{\text {hitung }}>t_{\text {tabel }}(14.429>2.447)$ dan nilai sig $(2$-tailed) adalah sebesar $0,000<0.05$ sehingga Ho di tolak dan Ha di terima. Sehingga dapat disimpulkan penerapan layanan bimbingan kelompok dengan media audio visual dapat meningkatkan minat belajar siswa kelas X MIPA V MAN Kota Palangka Raya.
\end{abstract}

Kata kunci: Bimbingan Kelompok, Media Audio Visual, Minat Belajar 


\title{
Abstract
}

\begin{abstract}
Application of Group Guidance Services Using Audio-Visual Media in Increasing Student Interest in Class $X$ Mipa $V$ During the Pandemic Period in Man City, Palangka Raya. This study aims to see the results of increased interest in learning with the application of group guidance services using audio-visual media. The studyemployed a descriptive quantitative approach and a method of experimentation with the design of one group of test-pretests and posttests. The study involves all X MIPA V MAN city of Palangka Raya students as a population and selection of samples by impressive sampling, selected 8 students who were used as samples. The data in this study was retrieved using 30 pest-interest items. Based on data analysis obtained after treatment of a three-time audio-visual media group guidance service, which indicates an increase in the interest of studying X MIPA V MAN city of Palangka Raya. The research found $t_{-}$(count)> table $(14,429>2,447)$ and sig's value (2-tailed) is of 0,000 <.05 that Ho is declined and Ha accepted. Thus summarized the application of group guidance services with visual audio media can increase the interest of studying students X MIPA VMAN city of Palangka Raya.
\end{abstract}

Keywords: Group Guidance, Audio-Visual Media, Interest In Learning

\section{A. Pendahuluan}

Pada tanggal 24 maret 2020 Menteri Pendidikan dan Kebudayaan Republik Indonesia mengeluarkan Surat Edaran Nomor 4 Tahun 2020 Tentang Pelaksanaan Kebijakan Pendidikan Dalam Masa Darurat Penyebaran COVID, dalam Surat Edaran tersebut dijelaskan bahwa proses belajar dilaksanakan di rumah melalui pembelajaran daring/jarak jauh dilaksanakan untuk memberikan pengalaman belajar yang bermakna bagi siswa. Menurut Isman dalam Dewi (2020), pembelajaran daring merupakan pemanfaatan jaringan internet dalam proses pembelajaran. Dengan pembelajaran daring siswa memiliki keleluasaan waktu belajar, dapat belajar kapanpun dan dimanapun. Siswa dapat berinteraksi dengan guru menggunakan beberapa aplikasi seperti classroom, video converence, telepon atau live chat, zoom maupun melalui whatsapp group. Pembelajaran ini merupakan inovasi pendidikan untuk menjawab tantangan akan ketersediaan 
sumber belajar yang variatif. Keberhasilan dari suatu model ataupun media pembelajaran tergantung dari karakteristik peserta didiknya.

Dalam hal keberhasilan siswa pada proses pembelajaran dapat dipengaruhi oleh dua faktor yaitu faktor dari dalam individu maupun dari luar individu itu sendiri. Salah satunya yang merupakan factor dari dalam diri siswa adalah minat, minat sangat menentukan tingkat keberhasilan belajar siswa. Minat menjadi salah satu faktor yang turut menentukan keefektifan belajar dan menentukan hasil belajar yang lebih baik. Intensitas minat seorang siswa akan sangat menentukan tingkat pencapaian prestasi belajarnya. Hurlock (2004: 116), berpendapat bahwa minat belajar dapat diamati dari dua aspek yaitu aspek kognitif dan aspek afektif. Aspek-aspek yang termasuk dalam aspek afektif yaitu kebutuhan informasi, rasa ingin tahu, perhatian, perasaan senang, kemauan belajar. Usaha yang akan dilakukan dalam rangka meningkatkan minat belajar siswa yang rendah adalah dengan mengoptimalkan layanan BK kepada siswa. Selain itu media yang digunakan dalam pembelajaran sangatlah mempengaruhi keberhasilan pembelajaran. Salah satu layanan yang dapat diberikan kepada peserta didik adalah dengan layanan bimbingan dan konseling, tujuan bimbingan dan konseling adalah untuk mengembangkan potensi pada individu seoptimal mungkin, sesuai dengan kemampuan agar bisa menyesuaikan diri dengan lingkungannya, baik lingkungan sekolah, keluarga maupun lingkungan masyarakat (Bastomi, 2020). Menurut Yusuf \& Nurihsan dalam Bastomi (2019) Proses Bimbingan dan Konseling di sekolah dapat berhasil apabila mempunyai tujuan yang jelas yang akan dicapainya. Bimbingan dan konseling bertujuan untuk membantu peserta didik agar dapat mencapai tujuan-tujuan perkembangannya yang meliputi aspek pribadi-sosial belajar (akademik) dan karir. Sedangkan tujuan bimbingan dan konseling Islam menurut Mubarok dalam Bastomi (2017) Secara singkat dapat dirumuskan sebagai berikut : (1) Tujuan umum Konseling Islam untuk membantu konseli agar dia memiliki pengetahuan tentang posisi dirinya dan memiliki keberanian mengambil keputusan, untuk melakukan suatu perbuatan yang dipandang baik, benar dan bermanfaat, untuk kehidupannya di dunia dan untuk 
kepentingan akhiratnya. (2) Tujuan khusus bimbingan konseling Islam adalah: (a) Untuk membantu konseli agar tidak menghadapi masalah. (b) Untuk membantu konseli mengatasi masalah yang sedang dihadapinya. (c) Untuk membantu konseli memelihara dan mengembangkan situasi dan kondisi yang baik atau yang telah baik agar tetap baik, sehingga tidak akan menjadi sumber masalah bagi dirinya dan orang lain. Guna mencapai tujuan bimbingan konseling sesuai yang diharapkan tentunya proses manajemen bimbingan dan konseling harus berjalan dengan sangat baik. Adapun layanan bimbingan dan konseling dalam penelitian ini adalah layanan bimbingan kelompok.

Dalam era perkembangan Iptek yang begitu pesat dewasa ini, profesionalisme guru tidak cukup hanya dengan kemampuan membelajarkan siswa, tetapi juga harus mampu mengelola informasi dan lingkungan untuk memfasilitasi kegiatan belajar siswa, , Ibrahim, et.al. dalam Daryanto (2016: 56), Beberapa penelitian menunujukkan bahwa informasi yang ditampilkan melalui gambar dapat diserap baik oleh penonton. Sedangkan apabila disampaikan melalui suara, informasi tersebut hanya bisa diserap dengan baik oleh penonton sebesar 40\% saja (Daryanto, 2016: 112).

Dalam penelitian ini, peneliti menggunakan layanan bimbingan kelompok dengan media audio visual karena menurut peneliti siswa dapat bersama-sama berbagi alternatif-alternatif yang dapat diaplikasikan anggota kelompok, serta dapat melatih keberanian siswa untuk mengemukakan pendapat dan bertanya kepada guru maupun teman. Sehingga dari penjelasan tersebut dapat disimpulkan bahwa layanan bimbingan kelompok menggunakan media audio visual dapat digunakan untuk membantu siswa dalam rangka mengaplikasikan alternatifalternatif dalam peningkatan minat belajar.

\section{B. Metode}

Penelitian ini menggunakan pendekatan kuantitatif yang bersifat penelitian ekperimen. Pelaksanaan penelitian eksperimen ini meliputi tes awal (Pre test), dan tes akhir (Post test). Untuk menguji hasil pelaksanaan layanan bimbingan 
kelompok dengan media audio visual dan kemudian membandingkan hasil dari tes akhir dengan tes awal, sebelum penerapan layanan bimbingan kelompok dengan media audio visual. Desain yang di gunakan dalam penelitian ini yaitu satu kelompok Pretes-Postes (The One Group Pretest-Postest).

Populasi pada penelitian ini adalah siswa kelas X MIPA (sepuluh) di MAN Kota Palangka Raya yang berjumlah 32 siswa dan jumlah sampel yang diambil yaitu 8 siswa dengan menggunakan teknik purposive sampling dalam pengampilan sampelnya. Variabel bebas pada penelitian ini yaitu layanan bimbingan kelompok dengan media audio visual, sedangkan variabel terikatnya yaitu

meningkatkan minat belajar. Instrument yang digunakan pada penelitian ini yaitu angket minat belajar, yang dimana pada setiap itemnya merupakan bagian dari aspek-aspek minat belajar. Sedangkan analisis data pada penelitian ini menggunakan analisis non parametris dengan menggunakan uji t-test, dan peneliti menggunakan alat bantu berupa program SPSS versi 25 dalam pengelolaan data pada uji t-test.

\section{Pembahasan}

\section{Layanan Bimbingan Kelompok}

Bimbingan kelompok adalah suatu kegiatan yang dilakukan oleh sekelompok orang dengan memanfaatkan dinamika kelompok (Prayitno, 1995: 178). Menurut Prayitno dan Amti (2013: 309) bimbingan kelompok adalah layanan bimbingan yang diberikan dalam suasana kelompok. Sedangkan menurut Romlah (2001: 3) bimbingan kelompok merupakan salah satu teknik bimbingan yang berusaha membantu individu agar dapat mencapai perkembangannya secara optimal sesuai dengan kemampuan, bakat, minat, serta nilai-nilai yang dianutnya dan dilaksanakan dalam situasi kelompok. Bimbingan kelompok ditujukan untuk mencegah timbulnya masalah pada siswa dan mengembangkan potensi siswa. Berdasarkan definisi tersebut di atas, dapat disimpulkan bahwa bimbingan kelompok adalah layanan bimbingan yang dilaksanakan dalam suatu kelompok dengan memanfaatkan dinamika kelompok sehingga anggota dapat 
mengembangkan potensi diri sekaligus memperoleh manfaat dari pembahasan topik masalah.

Tujuan bimbingan kelompok dimaksudkan untuk memungkinkan siswa secara bersama-sama guna memperoleh berbagai bahan materi dari konselor yang ada sekolah sebagai narasumber yang bermanfaat untuk kehidupan sehari-hari baik sebagai individu maupun pelajar (Mugiarso, 2004: 66). Tujuan bimbingan kelompok menurut Prayitno (1995: 179), agar setiap peserta: 1) mampu berbicara di depan orang banyak, 2) mampu mengeluarkan pendapat, ide, saran, tanggapan dan perasaan kepada orang banyak, 3) belajar menghargai pendapat orang lain, 4) bertanggung jawab atas pendapat yang dikemukakannya, 5) mampu mengendalikan diri dan emosi, 6) dapat bertenggang rasa, 7) menjadi akrab satu sama lain, dan 8) membahas masalah atau topik-topik umum yang dirasakan atau menjadi kepentingan bersama. Sedangkan menurut Wibowo (2005: 18) tujuan yang ingin dicapai dalam bimbingan kelompok yakni pengembangan pribadi, pembahasan topik-topik atau masalah-masalah umum secara luas dan mendalam yang bermanfaat bagi para anggota kelompok sehingga terhindar dari permasalahan yang berkaitan dengan topik atau masalah yang dibahas.

Menurut Prayitno (2004: 4), dalam bimbingan kelompok ada tiga komponen yang harus dipenuhi, yaitu pemimpin kelompok, anggota kelompok dan dinamika kelompok.

a. Pemimpin Kelompok

Pemimpin Kelompok (PK) adalah konselor yang terlatih dan berwenang menyelenggarakan praktik konseling profesional. Sebagaimana jenis layanan konseling lainnya, konselor memiliki keterampilan khusus untuk menyelengarakan bimbingan kelompok. Pemimpin Kelompok (PK) berkewajiban menghidupkan dinamika kelompok antarsemua peserta seintensif mungkin yang mengarah kepada pencapaian tujuan-tujuan umum bimbingan kelompok. 
b. Anggota Kelompok

Tidak semua kumpulan atau individu dapat dijadikan anggota bimbingan kelompok. Untuk terselengaranya bimbingan kelompok seorang konselor harus membentuk kumpulan individu menjadi sebuah kelompok yang memiliki persyaratan sebagaimana tersebut di atas. Besarnya kelompok (jumlah anggota kelompok), dan homogenitas/heterogenitas anggota kelompok dapat mempengaruhi kinerja kelompok. Sebaiknya jumlah kelompok tidak terlalu besar dan tidak terlalau kecil. Kekurang efektifakan kelompok akan terasa jika jumlah kelompok melebihi sepuluh orang.

c. Dinamika Kelompok

Dalam kegiatan bimbingan kelompok, dinamika kelompok sengaja ditumbuh kembangkan, karena dinamika kelompok adalah hubungan interpersonal yang ditandai dengan semangat, kerja sama antar anggota kelompok, saling berbagi pengetahuan, pengalaman dan mencapai tujuan kelompok. Hubungan interpersonal ini yang nantinya akan mewujudkan rasa kebersamaan di antara anggota kelompok, menyatukan kelompok untuk dapat lebih menerima satu sama lain, lebih saling mendukung dan cenderung untuk membentuk hubungan yang bermakna di dalam kelompok.

Dinamika kelompok merupakan jiwa yang menghidupkan dan menghidupi suatu kelompok. Cartwight dan Zander dalam Wibowo, (2005, 62), mendeskripsikan bahwa: dinamika kelompok sebagai suatu bidang terapan yang dimaksudkan untuk meningkatkan pengetahuan tentang sifat dan ciri-ciri kelompok, hukum perkembangan interelasi dengan anggota, dengan kelompok lain, dan dengan anggota yang lebih besar.

Selanjutnya Jacobs dalam Wibowo $(2005,62)$, menyatakan bahwa dinamika kelompok mengacu kepada sikap dan interaksi pemimpin serta anggota kelompok. Dinamika kelompok sebagai kekuatan operasional suatu kelompok akan memicu adanya proses kelompok dalam melakukan pertukaran semangat dan interaksi di antara anggota kelompok dan pemimpin 
kelompok. Kehidupan kelompok dijiwai oleh dinamika kelompok yang akan menentukan gerak dan arah untuk mencapai tujuan bimbingan kelompok.

Bimbingan kelompok memanfaatkan dinamika kelompok sebagai media dalam upaya membimbing anggota kelompok dalam mencapai tujuan. Dinamika kelompok unik dan hanya dapat ditemukan dalam suatu kelompok yang benar-benar hidup. Kelompok yang hidup adalah kelompok dinamis, bergerak dan aktif berfungsi untuk memenuhi suatu kebutuhan dan mencapai suatu tujuan. Dalam bimbingan kelompok, anggota dapat memanfaatkan dinamika kelompok, para anggota kelompok mengembangkan diri dan memperoleh keuntungan lainnya. Arah pengembangan diri yang terutama adalah dikembangkan kemampuan-kemampuan sosial secara umum yang selayaknya dikuasai oleh individu yang berkepribadian mantap. Keterampilan berkomunikasi secara efektif, sikap tenggang rasa, memberi dan menerima toleransi, mementingkan musyawarah untuk mencapai mufakat dan sikap demokratis, dan memiliki rasa tanggung jawab sosial seiring dengan kemandirian yang kuat, merupakan arah pengembang pribadi yang dapat dijangkau melalui diaktifkannya dinamika kelompok.

Melalui dinamika kelompok, setiap anggota kelompok diharapkan mampu tegak sebagai seorang yang sedang mengembangkan kediriannya dalam berhubungan dengan orang lain. Ini tidak berarti bahwa kedirian sesorang lebih ditonjolkan dari pada kehidupan kelompok secara umum. Dinamika kelompok akan terwujud dengan baik apabila kelompok tersebut, benar-benar hidup, mengarah kepada tujuan yang ingin dicapai, dan membuahkan manfaat bagi masing-masing anggota kelompok, juga sangat ditentukan oleh peranan kelompok.

Menurut Prayitno (1995: 40-60), ada empat tahap pada pelaksanaan bimbingan kelompok yaitu: 
a. Tahap pembentukan

Tahap ini merupakan tahap pengenalan dan keterlibatan anggota ke dalam kelompok dengan tujuan agar anggota kelompok memahami maksud bimbingan kelompok, saling menumbuhkan suasana saling mengenal, percaya, menerima dan membantu teman-teman yang ada dalam anggota kelompok. Pemahaman anggota kelompok memungkinkan anggota kelompok aktif berperan dalam kegiatan bimbingan kelompok yang selanjutnya dapat menumbuhkan minat pada diri mereka untuk mengikutinya. Kegiatan yang dilakukan pada tahap ini adalah pengungkapan pengertian dan tujuan kegiatan kelompok dalam rangka pelayanan bimbingan kelompok; menjelaskan cara-cara dan azas kegiatan kelompok; anggota kelompok saling memperkenalkan diri dan mengungkapkan diri; dan melakukan permainan keakraban.

b. Tahap Peralihan

Tahap ini transisi dari pembentukan ke tahap kegiatan. Dalam menjelaskan kegiatan yang harus dilaksanakan, pemimpin kelompok dapat menegaskan jenis kegiatan bimbingan kelompok yaitu tugas dan bebas. Setelah jelas kegiatan apa yang harus dilakukan maka tidak akan muncul keraguan atau belum siapnya anggota dalam melaksanakan kegiatan dan manfaat yang diperoleh setiap anggota kelompok.

c. Tahap Kegiatan

Tahap ini merupakan tahap inti dari kegiatan bimbingan kelompok dengan suasana yang akan dicapai, yaitu terbahasnya secara tuntas permasalahan yang dihadapi anggota kelompok dan terciptanya suasana untuk mengembangkan diri, baik menyangkut pengembangan kemampuan berkomunikasi maupun menyangkut tentang pendapat yang dikemukakan oleh anggota kelompok. Kegiatan dilakukan pada tahap ini untuk topik tugas adalah pemimpin kelompok mengemukakkan topik untuk dibahas oleh kelompok, kemudian tejadi tanya jawab antara anggota kelompok dan 
pemimpin kelompok tentang hal-hal yang belum jelas mengenai topik yang akan dikemukakan oleh pemimpin kelompok. Selanjutnya anggota membahas topik tersebut secara mendalam dan tuntas, serta dilakukan kegiatan selingan bila diperlukan. Sedangkan untuk topik bebas, kegiatan yang akan dilakukan adalah masing-masing anggota secara bebas mengemukakan topik bahasan, menetapkan topik yang akan dibahas dulu, kemudian anggota membahas secara mendalam dan tuntas, serta diakhiri kegiatan selingan bila perlu.

d. Tahap Pengakhiran

Pada tahap ini terdapat dua kegiatan yaitu penilaian (evaluasi) dan tindak lanjut (follow up). Tahap ini merupakan tahap penutup dari serangkaian kegiatan bimbingan kelompok. Dalam kegiatan kelompok pemimpin kelompok berperan untuk memberikan penguatan (reinforcement) terhadap hasil-hasil yang telah dicapai oleh kelompok tersebut. Kegiatan yang dilakukan dalam tahap ini adalah pemimpin kelompok mengemukakan bahwa kegiatan akan segera diakhiri, pemimpin kelompok dan anggota mengemukakan pesan dan kesan dari hasil kegiatan, membahas kegiatan lanjutan dan kemudian mengemukakan pesan dan harapan.

\section{Media Audio Visual}

Istilah media audio visual terdiri dari tiga kata yaitu media, audio dan visual. Adapun arti dari ketiga kata tersebut adalah; kata media berasal dari bahasa Latin dan merupakan bentuk jamak dari kata "medium" yang secara harfiah berarti perantara atau pengantar informasi (Djamarah \& Zain, 2006: 120). Menurut Arief S. Sadiman, dkk., (2006: 6), media secara harfiah berarti perantara atau pengantar pesan dari pengirim pesan ke penerima pesan. Association for Education and Communication Technology (AECT) dalam Yusufhadi Miarso (2004: 456), mengartikan media sebagai segala bentuk dan saluran untuk proses transmisi informasi. Apabila media itu membawa pesan atau informasi yang bertujuan instruksional atau mengandung maksud-maksud pengajaran, maka media itu disebut media pembelajaran (Arsyad, 2011: 4). 
Audio visual berasal dari kata audible dan visible, audible yang artinya dapat didengar, visible artinya dapat dilihat (Sulaeiman, 1985: 11). Dalam Kamus Besar Ilmu Pengetahuan, audio adalah hal-hal yang berhubungan dengan suara atau bunyi (Dagun, 2006: 81). Audio berkaitan dengan indera pendengaran,pesan yang akan disampaikan dituangkan kedalam lambang-lambang auditif, baik verbal (kedalam kata-kata/ bahasa lisan) maupun non verbal (Sadiman et al., 2006: 49). Visual adalah hal-hal yang berkaitan dengan penglihatan; berfungsi sebagai penglihatan diterima melalui indera penglihatan; dihasilkan atau terjadi sebagai gambaran dalam ingatan (Dagun, 2006: 81). Jadi Audiovisual adalah alat peraga yang bisa ditangkap dengan indra mata dan indra pendengaran yakni yang mempunyai unsur suara dan unsur gambar (Poerbakawatja, 1982: 32).

Dalam proses belajar mengajar kehadiran media mempunyai arti yang cukup penting. Karena dalam kegiatan tersebut ketidakjelasan bahan yang akan disampaikan dapat dibantu dengan menghadirkan media sebagai perantara.5 Salah satu teknologi dalam proses pengajaran itu adalah memilih media pembelajaran. Media pembelajaran menurut Rossi dan Breidle adalah seluruh alat dan bahan yang dapat dipakai untuk tujuan pendidikan, seperti radio, televisi, buku, koran, majalah, dan sebagainya (Sanjaya, 2011: 204). Media pembelajaran inilah yang akan membantu memudahkan siswa dalam mencerna informasi pengetahuan yang disampaikan. Media pembelajaran menurut karakteristik pembangkit rangsangan indera dapat berbentuk Audio (suara), Visual (gambar), maupun Audio Visual.

Menurut Rudi Bertz, sebagaimana dikutip oleh Asnawir dan M. Basyirudin Usman, mengklasifikasikan ciri utama media pada tiga unsur pokok yaitu suara, visual, dan gerak. Bentuk visual itu sendiri dibedakan lagi pada tiga bentuk, yaitu gambar visual, garis (linier graphic) dan symbol. Seperti umumnya media sejenis media audio visual mempunyai tingkat efektifitas yang cukup tinggi, menurut riset, rata-rata diatas $60 \%$ sampai $80 \%$. Pengajaran melalui audio visual jelas bercirikan pemakaian perangkat keras selama proses belajar, seperti mesin proyektor film, televisi, tape recorder dan proyektor visual yang lebar (Arsyad, 2011: 30). 
Jadi pengajaran melalui audio visual adalah penggunaan materi yang penyerapannya melalui pandangan dan pendengaran serta tidak seluruhnya tergantung kepada pemahaman kata simbol-simbol yang serupa. Dalam penelitian ini Proses meningkatkan minat belajar peserta didik ini ditunjukkan pada proses bimbingan kelompok dengan media audio visual berupa video film pendek dalam meningkatkan minat belajar siswa kelas X MIPA V MAN Kota Palangka Raya.

\section{Minat Belajar Siswa}

Sebelum kita mengetahui minat belajar maka kita harus mengetahui pengertian minat dan belajar. Kata minat secara etimologi berasal dari bahasa inggris " interest" yang berarti kesukaan, perhatian (kecenderungan hati pada sesuatu), keinginan. Jadi dalam proses belajar siswa harus mempunyai minat atau kesukaan untuk mengikuti kegiatan belajar yang berlangsung, kare na dengan adanya minat akan mendorong siswa untuk menunjukan perhatian, aktivitasnya dan partisipasinya dalam mengikuti belajar yang berlangsung. Menurut Ahmadi (2009: 148),“Minat adalah sikap jiwa orang seorang termasuk ketiga fungsi jiwanya (kognisi, konasi, dan emosi), yang tertuju pada sesuatu dan dalam hubungan itu unsur perasaan yang kuat". Menurut Slameto (2003, p. 180), "minat adalah kecenderungan yang tetap untuk memperhatikan dan mengenang beberapa kegiatan". Sedangkan menurut Djaali (2008: 121), "minat adalah rasa lebih suka dan rasa ketertarikan pada suatu hal atau aktivitas, tanpa ada yang menyuruh". Sedangkan menurut Crow \& Crow (2008, p. 121), mengatakan bahwa "minat berhubungan dengan gaya gerak yang mendorong seseorang untuk menghadapi atau berurusan dengan orang, benda, kegiatan, pengalaman yang dirangsang oleh kegiatan itu sendiri". Dari beberapa pendapat para ahli diatas dapat disimpulkan bahwa pengertian minat adalah rasa ketertarikan, perhatian, keinginan lebih yang dimiliki seseorang terhadap suatu hal, tanpa ada dorongan.

Sedangkan Skinner dalam Walgito (2010: 184), memberikan definisi belajar "Learning is a process of progressive behavior adaptation". Sedangkan menurut Walgito (2010: 185), “belajar merupakan perubahan perilaku yang 
mengakibatkan adanya perubahan perilaku (change in behavior or performance)". Menurut Whittaker, dalam Djamarah (2011: 12), merumuskan bahwa "belajar sebagai proses dimana tingkah laku ditimbulkan atau diubah melalui latihan atau pengalaman". Demikian pula menurut Djamarah (2011: 13), belajar adalah "serangkaian kegiatan jiwa raga untuk memperoleh suatu perubahan tingkah laku sebagai hasi dari pengalaman individu dalam interaksi dengan lingkungannya yang menyangkut kognitif, afektif dan psikomotor". Demikian pula menurut Khodijah (2014: 50), belajar adalah sebuah proses yang memungkinkan seseorang memperoleh dan membentuk kompetensi, ketrampilan, dan sikap yang baru melibatkan proses-proses mental internal yang mengakibatkan perubahan perilaku dan sifatnya relative permanen. Dengan demikian dapat ditarik kesimpulan bahwa pengertian belajar adalah perubahan dalam diri pelajarnya yang berupa, pengetahuan, ketrampilan dan tingkah laku akibat dari interaksi dengan lingkungannya. Sedangkan, minat belajar adalah kecenderungan individu untuk memiliki rasa senang tanpa ada paksaan sehingga dapat menyebabkan perubahan pengetahuan, ketrampilan dan tingkah laku .

Dalam minat belajar memiliki beberapa ciri-ciri, Menurut Elizabeth Hurlock dalam Susanto (2013: 62), menyebutkan ada tujuh ciri minat belajar sebagai berikut: 1) Minat tumbuh bersamaan dengan perkembangan fisik dan mental, 2) Minat tergantung pada kegiatan belajar, 3) Perkembangan minat mungkin terbatas, 4) Minat tergantung pada kesempatan belajar, 5) Minat dipengaruhi oleh budaya, 6) Minat berbobot emosional, 7) Minat berbobot egoisentris, artinya jika seseorang senang terhadap sesuatu, maka akan timbul hasrat untuk memilikinya.

\section{Layanan Bimbingan Kelompok Dengan Media Audio- Visual Dalam Meningkatkan Minat Belajar Siswa}

Berdasarkan hasil analisis data yang peneliti lakukan dengan cara membandingkan hasil pretest dan posttest kepada delapan peserta didik kelas $\mathrm{X}$ MIPA V MAN Kota Palangka Raya, didapatkan skor pretest 66.12 dan posttest 102.5. Melalui proses analisis deskriptif dari delapan peserta didik yang memiliki 
minat belajar dalam kategori rendah, peserta didik yang dijadikan sebagai sampel penelitian ini merupakan gambaran kecil dari masalah mengenai minat belajar. Berdasarkan hasil observasi dan wawancara yang dilakukan peneliti ada beberapa peserta didik yang mengalami minat belajar yang rendah seperti peserta didik sering merasa bosan, sering melamun atau tidak memperhatikan, sering mematikan kamera saat pembelajaran, sering membolos, dan kurang tertarik dalam belajar.

Menurut Aritonang (2008), bahwa faktor-faktor yang membuat siswa berminat belajar yaitu cara mengajar guru, karakter guru, suasana kelas tenang dan nyaman, dan fasilitas belajar yang digunakan. Sehingga peneliti menggunakan media pembelajaran berupa media audio visual dalam penelitian ini. Proses meningkatkan minat belajar peserta didik ini ditunjukkan pada proses bimbingan kelompok dengan media audio visual berupa video film pendek dalam meningkatkan minat belajar siswa kelas X MIPA V MAN Kota Palangka Raya. Pemberian bimbingan kelompok dengan media audio visual ini dilakukan sebanyak tiga kali pertemuan. Setelah peneliti melaksanakan bimbingan kelompok dengan media audio visual dalam meningkatkan minat belajar, peneliti mengadakan posttest kepada peserta didik. Adapun persentase rata-rata skor pretest didapatkan sebesar $44.08 \%$ dan skor posttest sebesar $68.33 \%$, jumlah tersebut mengalami persentase peningkatan sebanyak $24.25 \%$. Sehingga dapat dikatakan bahwa hal ini menunjukkan adanya peningkatan minat belajar melalui pemberian bimbingan kelompok dengan media audi visual kepada peserta didik.

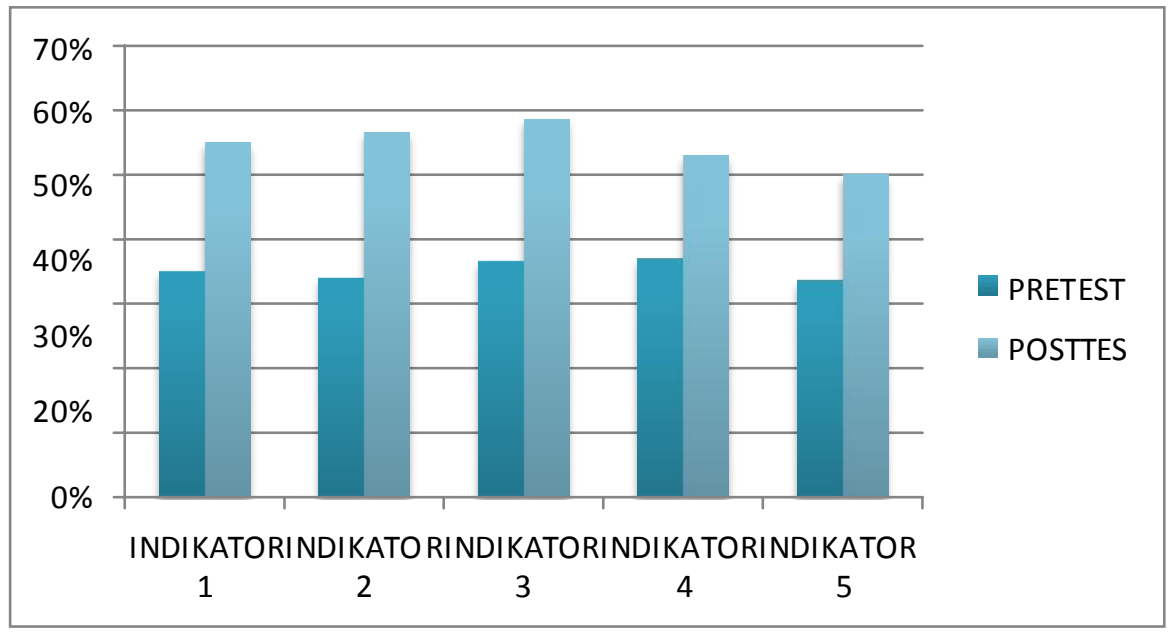


Gambar 1. Histogram Peningkatan Pre-Test Dan Post-Test Perindikator

Berdasarkan indicator yang di paparkan oleh Hurlock (2010:116), bahwa indicator dari minat belajar adalah kebutuhan informasi, rasa ingin tahu, perhatian, perasaan senang, kemauan belajar. Dari data diatas dapat kita lihat yaitu terdapat peningkatan yang cukup signifikan pada indicator - indikator minat belajar. Pada indicator 1 dengan persentase $35 \%$ (sangat rendah) dan setelah diberikan perlakuan meningkat menjadi 55 \% (tinggi), indicator 2 dengan persentase $34 \%$ (sangat rendah) meningkat menjadi $56.6 \%$ (tinggi), indicator 3 dengan persentase $36.6 \%$ (rendah) meningkat menjadi $58.6 \%$ (tinggi), indicator 4 dengan persentase $37 \%$ (rendah) meningkat menjadi $53 \%$ (tinggi), dan indicator 5 dengan persentase $33.6 \%$ ( sangat rendah) meningkat menjadi $50 \%$ (sedang). Pada peningkatan lima indicator minat belajar ditandai dengan adanya perubahan tingkah laku yang ditunjukkan oleh siswa. Pada indicator 1 yaitu kebutuhan informasi yang dimana siswa menunjukkan rasa bosan saat pembelajaran dikarenakan informasi yang disampaikan kurang menarik dan setelah diberikan perlakuan dengan menggunakan media audio visual terdapat perubahan yaitu siswa lebih tertarik dalam menerima informasi yang diberikan oleh guru BK. Pada indicator 2 yaitu rasa ingin tahu yang dimana siswa menunjukkan sikap sering mematikan kamera dikarenakan merasa penyampaian materi yang monoton dan membosankan sehingga mengakibatkan kurangnya rasa keingin tahuan terhadap materi yang diberikan dan ingin meninggalkan proses pembelajaran, dan setelah diberikan perlakuan siswa menjadi lebih tertarik dan tidak mematikan kamera saat pembelajaran. Pada indicator 3 yaitu perhatian yang dimana siswa menunjukkan kurang perhatian saat pembelajaran berlangsung dikarenakan media dan metode yang digunakan kurang menarik perhatian siswa dan setelah diberikan perlakuan terdapat perubahan berupa adanya ketertarikan dalam memperhatikan penyampaian guru BK pada saatpembelajaran berlangsung. Pada indicator 4 yaitu perasaan senang siswa menunjukkan kurang tertarikknya dalam belajar dan setelah diberikan perlakuan terdapat perubahan yaitu siswa lebih tertarik dalam belajar. Pada indicator 5 yaitu kemauan belajar siswa 
menunjukkan sikap sering membolos pada saat pembelajaran dikarenakan kurangnya minat dalam belajar dan setelah diberikannya perlakuan siswa lebih jarang meninggalkan kelas (room zoom/whatsapp group) pada saaat proses pembelajaran berlangsung.

Peningkatan minat belajar ini juga dibuktikan melalui analisis data yang diperoleh $t_{\text {hitung }}=14.429>t_{\text {tabel }}=2.447$, maka Ha diterima dan Ho ditolak. Sehingga dapat disimpulkan sesuai dengan hipotesis yang telah peneliti buat sebelumnya bahwa Ho yang berbunyi "Penerapan layanan bimbingan kelompok dengan media audio visual tidak dapat meningkatkan minat belajar siswa kelas $\mathrm{X}$ MIPA V pada masa pandemic di MAN Kota Palangka Raya tahun ajaran 2020/2021" ditolak, dan Ha yang berbunyi "Penerapan layanan bimbingan kelompok dengan media audio visual dapat meningkatkan minat belajar siswa kelas X MIPA V pada masa pandemi di MAN Kota Palangkaraya tahun ajaran 2020/2021" diterima. Sehingga dapat dikatakan penerapan bimbingan kelompok dengan media audio visual dapat meningkatkan minat belajar siswa kelas X MIPA 5 MAN Kota Palangka Raya. Hal ini sejalan dengan pendapat Daryanto (2016:6) media audio visual yakni segala sesuatu yang bisa dipergunakan dalam menyampaikan pesan, sehingga mampu manarik perhatian, minat, serta perasaan siswa dalambelajar untuk dapat mencapai tujuan pembelajaran.

Setelah diterapkannya bimbingan kelompok dengan media audio visual, dan dari analisis data penelitian terdapat peningkatan yang signifikan terhadap minat belajar siswa. Sehingga dapat ditarik kesimpulan bahwa penerapan bimbingan kelompok dengan media audio visual cukup efektif dalam meningkatkan minat belajar siswa.

\section{Simpulan}

Berdasarkan hasil pembahasan dari penelitian tentang penerapan layanan bimbingan kelompok dengan media audio-visual dalam meningkatkan minat belajar siswa kelas X MIPA V pada masa pandemi di MAN Kota Palangka Raya, maka dapat disimpulkan bahwa penerapan layanan bimbingan kelompok dengan 
media audio-visual dapat meningkatkan minat belajar siswa kelas X MIPA V di MAN Kota Palangka Raya. Hal ini diketahui juga dari hasil uji t diperoleh $t_{\text {hitung }}>$ $t_{\text {tabel}}(14.429>2.447)$ dan nilai sig (2-tailed) adalah sebesar $0,000<0.05$ sehingga Ho di tolak dan Ha di terima. 


\section{DAFTAR PUSTAKA}

Ahmadi, A. (2009). Psikologi Umum. Jakarta: Rineka Cipta.

Aritonang, Keke T. 2008. Minat dan motivasi dalam meningkatkan hasil belajar siswa. Jurnal Pendidikan Penabur,. http://digilib.unimed.ac.id (Diakses pada 15 Februari)

Arsyad, A. (2011). Media Pembelajaran. Jakarta: RajaGrafindo Persada.

Bastomi, H. (2017). Menuju Bimbingan Konseling Islami. KONSELING EDUKASI: Journal of Guidance And Counseling, 1 No. 1. https://doi.org/10.21043/konseling.v1i1.4434

Bastomi, H. (2019). Konseling Cyber: Sebuah Model Konseling Pada Konteks Masyarakat Berbasis Online. Konseling Edukasi: Journal of Guidance and Counselling, 3, No. 1.

Bastomi, H. (2020). Pemetaan Masalah Belajar Siswa SMK Negeri 3 Yogyakarta Dan Penyelesaiannya (Tinjauan Srata Kelas). KONSELING EDUKASI: Journal of Guidance And Counseling, 4 No. 1.

Dagun, S. M. (2006). Kamus Besar Ilmu Pengetahuan. Jakarta: Lembaga Pengkajian Kebudayaan Nusantara (LPKN).

Daryanto. (2016). Media Pembelajaran. Yogyakarta: Gava Media.

Dewi, W. A. F. (2020). Dampak Covid-19 terhadap Implementasi Pembelajaran Daring di Sekolah Dasar. Jurnal Ilmu Pendidikan, 2 No. 1.

Djaali. (2008). Psikologi Pendidikan. Jakarta: Bumi Aksara.

Djamarah, S. B. (2011). Psikologi Belajar. Jakarta: Rineka Cipta.

Djamarah, S. B., \& Zain, A. (2006). Strategi Belajar Mengajar. Jakarta: Rineka Cipta.

Hurlock, E. B. (2004). Psikologi Perkembangan: Suatu Pendekatan Rentang Kehidupan. Jakarta: Erlangga.

Khodijah, N. (2014). Psikologi Pendidikan. Jakarta: Rajawali Pers.

Miarso, Y. H. (2004). Menyemai Benih Teknologi Pendidikan. Jakarta: Kencana.

Mugiarso, H. (2004). Bimbingan dan Konseling. Semarang: UNNES Press.

Poerbakawatja, S. (1982). Ensiklopedi Pendidikan. Jakarta: Gunung Agung.

Prayitno. (1995). Layanan Bimbingan Dan Konseling Kelompok Dasar Dan Profil. Jakarta: Rineka Cipta. 
Prayitno. (2004). Layanan Bimbingan Kelompok Dan Konseling Kelompok. Padang: Universitas Negeri Padang Press.

Prayitno, \& Amti, E. (2013). Dasar-Dasar Bimbingan Dan Konseling. Jakarta: Rineka Cipta.

Romlah, T. (2001). Teori dan Praktek Bimbingan dan Konseling Kelompok. Malang: Universitas Negeri Malang Press.

Sadiman, A. S., Rahardjo, R., Haryono, A., \& Harjito. (2006). Media Pendidikan Pengertian, Pengembangan dan Pemanfaatannya. Jakarta: RajaGrafindo Persada.

Sanjaya, W. (2011). Perencanaan dan Desain sistem Pembelajaran. Jakarta: Kencana.

Slameto. (2003). Belajar dan Faktor yang Mempengaruhinya. Jakarta: Rineka Cipta.

Sulaeiman, A. H. (1985). Media Audio-Visual untuk Pengajaran, Penerangan, dan Penyuluhan. Jakarta: Gramedia.

Susanto, A. (2013). Teori Belajar dan Pembelajaran di Seklah Dasar. Jakarta: Kencana Prenada Media Group.

Walgito, B. (2010). Pengantar Psikolog Umum. Yogyakarta: Andi Offset.

Wibowo, M. E. (2005). Konseling Kelompok Perkembangan. Semarang: Universitas Negeri Semarang Press. 